定の性質の膜を歩留りよく作るには，在来の真空技術の みに基づいた蒸着装置では簡単に処理できない。

最近の蒸着技術の動向の一つは, かかる蒸着条件制御 機能の開発実用化であろう。帛第一は雾囲気制御技術 で, ソープションポンプとイオンポンプを組合せた，污 染のない超高真空系と, ラミナーフローを発生させ, 室 内の塵埃の侵入を予防するクリーンベンチであろう、第 二に不純物の混入防止対策として, 電子ビ一ム加熱蒸着 源が製品化されたことで，水冷銅るつぼの採用により， るつぼと溶融金属との反応がなくなった。これはまた高 融点金属の蒸着や，A1の大量蒸着にも適している。第 三は水晶式膜厚計および蒸着速度計が開発され蒸着しな がら膜厚と速度が監視でき， SCR 制御電源やシャッタ 系と組合わせ礼ば，蒸着自動制御ができ，操作が非常に 容易になった。

一方スパッタリング技術もここ数年来非常に進歩し， 装置む改良されてきた. 中でも四極スパッタ装置は, 放 電が安定なこと，スパッタ条件を広範囲に変えられるこ と, 低圧 $\left(10^{-3}\right.$ Torr $)$, 低エネルギ（1 KV以下）でスパ ッタできるなどの利点があり, 薄膜 IC, 半導体 IC の両 分野で注目されている。蒸着技術の第二の動向は排気の 自動化, 排気時間の短縮による作業性の向上であろう. 以前から VEECO社の VE-775 で実現されていたが， 極最近, 日本真空技術でも $10^{-7}$ torr の到達圧力の油拡 散ポンプ系蒸着装置で実現している。

第三の動向としては薄膜量産機器の開発で, 半連続方 式はすでに実用化されているが, 最近では鋼板のアルミ ナイズとか薄膜スパッタ等に捺いて，「大気から大気」 方式の多槽連続方式が開発された。 また電子ビーム加工 技術を製造工程の中に取入れて，回路パターンの作製も 同時に行なわれようという構想も提案されている.

第四の動向としてはIC の新しい製作法に連がる技術 であろうＩCでは回路のアイソレーション,キャパシ 夕用誘電体や保護膜として, 酸化物や窒化物の誘電体膜 が利用されている。これは従来シリコンの気相酸化か酸 化物の蒸着に依存していたが，1965年 Davidse らは $\mathrm{RF}$ スパッタリングにより, シリカやガラス板を直接大 パッタして, シリコン表面を被覆することに成功した. これは二極あるいは四極方式で, ターゲットに $13.56 \mathrm{Mc}$ のRF電圧を印加すればよい。

これら二極あるいは四極方式の RF スパッタでは，プ ラズマ集束用磁石を必要とするのに対し，Varianの Lothrop と Herte は二枚のターゲットを逆 V 字型に 並べ，底辺に基板ホルダを置いて接地電位とした"プラ ズマピーグスパッタ装置を開発し, 磁場がなくても 10-4 torr台で放電を維持できることを示した。
最後にこれはいわゆる蒸着ではないが，半導体へのイ オン注入技術を挙げる必要があらう. 現在半導体表面層 の不純物制御は専ら熱拡散法で行なわれているが，ここ 数年来, 不純物原子を真空中でイオン化して半導体表面 に注入する技術が研究され，新しい半導体製造技術の一 つと見做されるようになった。

注入には 1〜 50 KeVの低エネルギイオンを利用する方 法と， $50 \mathrm{KeV}$ 2MeVの高エネルギイオンを利用する方 法の二通りがあり，目的のイオンのみを表面に注入する ため，質量分析用マグネットの極間を通過させる．今ま での実験例では Si に対し $\mathrm{B}^{+}, \mathrm{N}^{+}, \mathrm{D}^{+}, \mathrm{P}^{++}, \mathrm{K}^{+}, \mathrm{Cs}^{+}$等 が注入されている。この技術の特長は(1)イオンエネルギ を制御することにより，表面層の不純物分布を制御でき ること，(2)比較的低温度で不純物を導入できること，(3) イオンビームの電流とスポット径, 位置を電気的に制御 するここにより，任意の場所に任意の大きさの $\mathbf{p}-\mathbf{n}$ 接合 を作りうる，(4)表面酸化層を通して不純物を注入できる こと等にある。

以上最近の蒸着技術の進歩について，製造に利用され ているもの, 近い将来兄の可能性の濃厚なものを紹介し た。

\section{3. 薄膜とエレクトロニクス}

$$
\text { 本多進* }
$$

エレクトロニクスに用いられる薄膜関係では，昨年は これまでに検討されてきた新技法を更に応用面に導入し ようとする積極的な動きがみられ，それらは特にマイク ロエレクトロニクスの分野を中心として著しいものがあ り, 実用化への歩みを着実に踏み出した 1 年とみること ができる。

薄膜の構造や形成過程に関する未解決分野での基本的 な問題は，国内外で活発に研究が続けられている。気相 と固相との表面相互作用については，身近なるのになっ た超高真空技術を応用して, LEED, FEM, 分子線などに より, 固体清浄表面の構造, ガス吸着機構, 気体と固体 表面のエネルギー交換等, 多くの基礎的研究が進められ た.また,ここ 1,2 年の新しい動きは, 蒸着膜の成長過程を 直接電子湿微鏡映画に撮影して観察することで，昨年春 の応物関倸連合講演会や，昨年 6 月 Budapestで開催さ れた薄膜コロキウムなどで競演されており，薄膜成長の メカニズムや膜の成長過程における内部応力の発生機構 等を新しい角度からとらえようとする点で注目される。

一方, 薄膜の応用面での成果は, 主として IC p半導

* 東京芝浦電気株式会社集皘回路技術部 
体, 磁性薄膜関係で活発なものが夕られる。

薄膜受動素子のうち, 抵抗薄膜については, 真空蒸着

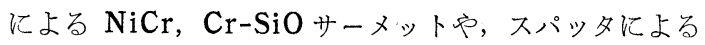
$\mathrm{Ta}, \mathrm{TaN}$ が主力を占めている。 NiCr 抵抗膜については Al, Be, Si などを添加して TCR や安定性の改良を計 ったり，岩塩の䢃開面に蒸着した膜の基本的検討などが 行なわ秃た。しかし, 単体抵抗としての実用化が最子進 えでいる $\mathrm{NiCr}$ については，2,3 年前に比べて新しいも のは少なく, むしろ研究の動向はTa薄膜に移行した感が ある. 薄膜 IC 用に開発されたTa系抵抗体は, 高安定, 高 精度のbのが得られるため, BTLでの実用化と相まっ て， $\mathrm{N}_{2}$ 雺囲気中で反応性スパッタした膜や陽極化成し た膜の, 構造解析や抵抗膜としての特性結果が多く報告 されている。おもに応用に関する報告が多いが，新しい $\beta-\mathrm{Ta}$ の構造解析や, 非対称交流スパッ夕による高純度 $\mathrm{Ta}$ 膜の生成機構の研究などもタられる. その他, 高抵 抗が得られる $\mathrm{Cr}-\mathrm{SiO}$ 膜の電導機構や雑音解析, $\mathrm{O}_{2}$ 中 での $\mathrm{Sn}$ や $\mathrm{Sn}-\mathrm{Sb}$ の反応性スパッタによる $\mathrm{SnO}_{2}$ 膜の 解析などが行なわれた。

コンデンサ用の誘電体薄膜に関する動きは, 材料的に みると抵抗より種類が多く各種のものが研究されている が, 抵抗膜と違って, 歩留り, 信頼性, 大容量が得られな い等の点で実用化の域に達しているものは少ない。この 分野では反応性スパッタや RF スパッ从による誘電体膜 の製法が一般化したといえるのがここ 1,2 年の傾向であ る. しか子抵抗と同様に Ta 膜に関するものが最も多い のも特長である. $\mathrm{O}_{2}$ 雲囲気中で反応性スパッタした, $\mathrm{Ta}_{2} \mathrm{O}_{5}, \mathrm{Al}_{2} \mathrm{O}_{3}, \mathrm{Y}_{2} \mathrm{O}_{3}$ 膜の解析や, 金属, II - VI 族 化合 物等を不活性ガスと $\mathrm{H}_{2} \mathrm{~S}$ の混合ガス中でスパッタして得 られる硫化膜の特性等に関する報告が多い. $\mathrm{Ta}_{2} \mathrm{O}_{5}$ 膜は Ta 抵抗と組合せた薄膜回路の応用面で有用であるが, 高周波特性や信頼性などの点で若干問題を残している. $\mathrm{RF}$ スパッ夕によると絶縁物を直接薄膜化して絶縁抵抗 や損失等の優れた誘電体膜が得られるので, $\mathrm{Al}_{2} \mathrm{O}_{3}$, $\mathrm{MgO}, \mathrm{BaTiO}_{3}$, 石英等について活発な研究が行なわれ ている.

また電子ビームによる誘電体膜の重合も盛えになり， 有機モノマーからシクロセンやジメチルポリシロキ少 ン, エポキシ等の重合膜を作る研究が行なわれ，ピンホ 一ルや内部ひずみの少ない均一な膜が得られるようにな った．また珪酸エチルを電子ビーム衝撃して励起させ， $\mathrm{SiO}_{2}$ 膜を作り, 高周波用コンデンサに利用する試みる 行なわれた。

$\mathrm{SiO}$ や $\mathrm{TiO}_{2}$ コンデンサに関する研究はこの所やや停 滞しているが, 特性や信頼性に問題を残しており, 完成し たというよりは問題点が明らかになって再検討の時期に
入ったとみるのが妥当のようである. SiOについては, $\mathrm{La}, \mathrm{Bi}, \mathrm{Co}$ 等の酸化物を混入乙て蒸着し, Q に好結果を得ている。

薄膜インダクタについては劃期的なものは依然として みられない。しかし, フェライト薄膜を得る実験では, $\mathrm{Fe}_{3} \mathrm{O}_{4}$ や $\gamma-\mathrm{Fe}_{2} \mathrm{O}_{3}$ をフラッシュ法で蒸着したり, $95 \%$ $\mathrm{Fe}_{3} \mathrm{O}_{4}-5 \% \mathrm{~B}_{2} \mathrm{O}_{3}$ 真空蒸着後焼鈍したbの, 或いは $\mathrm{Fe}_{2}$ $\mathrm{O}_{3}$ を真空アーク蒸着したものなどについて電子回折や FMR測定を行ない，完全に近いフエライト膜が確認さ れたという報告子みられる。

一方, 磁性薄膜関係で現在最も活発な動きをみせてい るのはメモリー関係である：との分野は以前よりプラナ 方式とワイヤ方式とに分かれて基本的な研究が行なわれ てきたが，昨年は実用化の面で大きく前進したととと， 更にこの方式のほかに半導体メモリーが容量の小さい分 野で商品化の戦列に加わって三つどもえの様相を呈して きたことが注目される.昨秋米国で開かれたFall Joint Computer Conferenceの席上でもとの 3 方式のメモリ 一がとりあげられ, 活発な論議がたたかわされた。それぞ れ特長, 欠点を有して括り，今後いずれが伸びるかは本年 以降の動きにかかっている，ての分野では，パーマロイ。 に第 3 元素を添加してこれをバイアススパッタ法で蒸着 し, 異方性磁界, 角度分散などを小さく守る試みや，以 前に引きつづいて基板の表面状態や蒸着中の残留ガスと 磁気特性の関係などについての報告が多い。このほか磁 性薄膜と超音波パルスを組合せたsonic film memory (RCA)や, Kerr効果を応用した EuO 薄膜メモリ一 (IBM)などの開発も行なわれた。

能動素子に灾用される薄膜に関しては極めて報告が多 い. 薄膜のhetero junction の特性に関する報告は多 く, プラズマ酸化による $\mathrm{Al}_{2} \mathrm{O}_{3}$ 一金属系の電導機構や, $\mathrm{CH}_{4}$ と $\mathrm{Si}$ の高温反応による金属- $\beta \mathrm{SiC} の$ schottky diodeの特性などが報告された。 また金属薄膜と半導体と のダイオード特性を蒸着䨌囲気との関連において求め, イオンポンプによる $10^{-5}$ torr より低真空の領域および 油拡散ポンプの使用では，清浄な金属と半導体との接触 が得られないことなどが指摘された. hetero epitaxyに ついては古くから研究されているが，ICに护る素子間 の絶縁分離や相補形素子の組合せなどを目的として絶縁 基板上へ単結晶膜を成長させる方式がここ 1,2 年の間 に急速に伸びてきた。中でもSOS構造についての結晶成 長，電気特性等に関する報告が多く,(1012) 方位の基板 を使ってモノシランを気相成長させたものは，バルクの 80\%以上に達するホール移動度が得られている. SOSを 利用したIC情でに実用化ざれはじめ，100ビットのシ フトレジスタや相補形の MOS-FET を含きICなどが米 
国で作られている。

一方, 薄膜トシンジスタとして Weimer が開発した TFTは, 2, 3年前过は強力な研究が行なわれ, 試作品も 種々作られたが, 再現性, 安定性, 周波数特性などの点 で問題があり，SOS 技術の発展とは逆にやや停滞した 感がある、とはいえ，CdS，CdSe等の蒸着条件や，ガ大 忣着効果が能動素子に与える影響等のほか，トラップに よる過渡応答については， $\mathrm{Al}_{2} \mathrm{O}_{3}$ - InAs の組 合せでトラ ップ効果のないTFTを作り，リニア動作をさせるなど の報告もある、新しい試みとしては, schottky barrier を用いた TFTとか，後述の厚膜の印刷によるTFTな どもみられる。

また，トランジス从やIC 表面の安定化, FETの絶縁 膜, 選択昖散用マスク, IC の多層配線用絶縁膜なざに 低温度で形成できる高純度の絶縁膜が必要で, スパッタ 膜が注目されている。特に前 2 者に使用される絶縁膜は $\mathrm{Na}^{+}$により表面電位が変化するため, $\mathrm{Na}^{+}$の拡散係数の 小さい $\mathrm{Si}_{3} \mathrm{~N}_{4}$ 膜の検討がなされ, $\mathrm{SiH}_{4}, \mathrm{SiCl}_{4}$ 等と $\mathrm{NH}_{3}$, $\mathrm{H}_{2}$ との反応による気相成長や, $\mathrm{Si}$ の $\mathrm{N}_{2}$ 舅囲気中での 反応性スパッタ, $\mathrm{Si}_{3} \mathrm{~N}_{4}$ の直接 $\mathrm{RF}$ スパッタなどが検討 された。 $\mathrm{Si}_{3} \mathrm{~N}_{4}$ のスパッタ膜はピンホールのない良好な 絶縁膜が低温で得られるととで注目され報告も多くみら れる. $\mathrm{Si}_{3} \mathrm{~N}_{4}$ 膜は $\mathrm{Na}^{+}$の影響を少なくするほか，外気と の遮断を完全にするため, 逆耐圧の低下や過剩漏洩電流 が防止され信頼度が上昇するので，米国で㤬すでに $\mathrm{Si}_{3} \mathrm{~N}_{4}$ でパッシベイトされた能動素子の市販が開始さ れた。乙れに関連してMOSをMNS構造に打きかえる ことによりアルカリイオンドリフトを防ぐほか，表面準 位密度や移動度の制御を行なうなどの報告もみられる。

このほか, 薄膜応用技術面では, 電子ビームを非熱的 に利用して拡散やェッチングのマスクを形成したり，

ion implantation による不純物注入法などの例が次 第に多くなってきている. てれら電子ビームやイオンビ 一ムを利用する一連の技術は, 電子計算機による自動生 座が可能な点で本年は国内外に打いて吏に研究が活発化 守るものと思われる。

一方, 昨年は薄膜の量産装置や自動生産装置の製造も 各所で行なわれ，国内でも開端システムの $\mathrm{Ta}$ 薄膜連続 スパッタ装置や電子ビーム露光装置が作られるなど活発 な動きがみられた。

以上述べたような薄膜䋕子や製造装置の開発と関連し て薄膛 IC の試作例も多いが, 中でも Ta薄膜とビーム リードICの組合せによりタッチトーン発振 器その他を 量産化して電話器や電子交換機に実用化した例 (BTL) は昨年の特筆すべき事項といえよう。

以上は薄膜関係の動向であるが, 最後に厚膜技術関係
について若干ふれておく、ハイブリッドIC と薄膜技術 との結びつきはすでに長いが，IBM のSLT の成功に より一躍脚光を浴びてきたのが厚膜技術であり，とと 1, 2 年急激な伸長をみせている.乙机过は受動素子の厚 膜化が主体であったが，昨年，厚膜能動素子の発表がな されて以来，更に動きが活発化してきた。乙れはCdSや CdSeのペーストを印刷, 焼成した上にSiO, A1 を蒸着 して coplanar type の電界效果トランジスタとしたも ので，更に全てを厚膜で形成しようとする意照的な動き もすでに一部でみられる。これら厚膜素子はいずれも実 用化が基礎研究に先行した感があるが, 厚膜の基本的研 究は今後の厚膜の発展と相なって是非共行なわなければ ならない重要な課題である.こうした点から, 昨年 2 月 米国で第1回の Technical Thick Film Symposium が開催され，更に昨年 5 月に米国で発足したInternational Society for Hybrid Microelectronics の主 催で10月には Hybrid Microelectronics Symposium が開かれ，薄膜厚膜を含む膜回路の基礎的問題や製造技 術について討議された。こうした動きに呼応して, 国内 でも学振第131委員会で昨秋, “薄膜技術か厚膜技術 か、に関するパネルデイスカッションが開かれ，それに 引きつづいて昨年末には厚膜技術研究委員会の設立も み, 薄膜と並行して厚膜技術の基礎と応用面での活発な 活動を行なうととになった，そして本年初めより具体的 な活動に入るととになっている.

こうした意味から，本年はェレクトロニクスの分野で の薄膜・厚膜に関して更に発展が期待される. 㕕範な工 レクトロニクスの全分野を網羅するととは困難で，いさ さか近視眼的になってしまった点を打許しいただきた w.

\section{4. クライオゼニックスの真空工学へ の応用}

$$
\text { 石井寿一* }
$$

元来学問としても技術としても互いに似たような性格 定もっている真空と低温は, 從来も互い络《の一手段 として相互利用は行なわれていたが，との一例として最 近の宇宙開発の進歩に伴ない大型のスペースチェンバー の要求が生をれ, より密接にしか子大規模仙両方の技術 が結合するととになった。少なわち, 地上に执いて宇宙 空間を再現ずるために高真空の久ならず熱バランスのた めに低温が要求されるのでスペースチェンバーは液体空 素シュラウドが必要である．とのシュラウドは真空用の

* 日本酸素 (㧣) 東京製作所 